DOI https://doi.org/10.18551/rjoas.2018-07.14

\title{
DISCLOSURE OF MEANING BEHIND THE EXISTENCE OF PROCUREMENT CLINIC OF GOVERNMENT GOODS AND SERVICES IN THE UNIT OF PROCUREMENT SERVICES OF BADUNG REGENCY
}

\author{
Martini Ida Ayu Agung Sri \\ Graduate Program, University Udayana, Bali, Indonesia \\ E-mail: adityapalguna21@gmail.com
}

\begin{abstract}
This study aims to reveal the meaning behind the existence of procurement clinic of government goods and services at the Procurement Unit of Badung Regency. The research was conducted in Badung Service Procurement Unit on two informants that directly related to the process of the establishment of goods and service procurement clinic, namely the secretary of the Service Unit of Procurement of Goods and Services and Procurement Champions on the goods and services procurement clinic. The findings indicate that the existence of the goods and services procurement clinic is underpinned by the need for the media to carry out consultations on the procurement process of government goods and services and the rewards given in the form of procurement modernization training by the Government Procurement Policy Agency.
\end{abstract}

\section{KEY WORDS}

Positive image, workload, phenomenology, government, goods, services, procurement clinic.

Characteristics or key elements of good governance are accountability, transparency, openness, and the rule of law (Nisjar 1997). Good Governance will be able to recognize what the needs, problems, desires and interests and aspirations of the people properly and correctly, therefore the policies made will be able to reflect what interests and aspirations of the people it serves (B. Smith, 1985).

Indonesia as a developing country and it is trying to realize the ideals of the nation for the achievement of social welfare, the development of facilities and infrastructure related to the public interest becomes very important to be realized. The provision of goods and services is an important part of governance (Simamora, 2013). Not all goods and services available can be provided by the private sector. Goods and services that can not be provided by this market system are called public goods, ie goods that can not be provided through transactions between the seller and the buyer (Due \& Friedlaender, 1993). The market system can not provide certain goods or services because the benefits of the goods are not solely enjoyed personally but also by others.

In order to improve professional procurement operations work, to avoid any conflicts of interest, and to avoid fraud in the procurement of goods and services at the Ministries / Institutions / Agencies / Governmental Institutions (K / L / D / I) levels, the government also requires every K / L / D / I to establish the Procurement Services Unit (ULP). The Badung Regency, Based on Badung Regent's Decree Number 70 of 2011 dated 10 November 2011 established the Procurement Services Unit (ULP) of Badung Regency with 9 (Nine) working groups. ULP Badung Regency was nominated as ULP of National Pilot, from the achievements that have been received, it does not mean that the government of Badung Regency is free from the problems related to the procurement of government goods and services. The was a case of alleged misuse of water meter procurement funds in the Local Government-Owned Running Water Enterprise of PDAM Tirta Mangutama Badung in 2016. This case indicated manipulation of costs for procurement of water meters. Other cases, such as allegations of irregularities or corruption in the project of river bank's construction along Tukad Mati in Legian area of Kuta in 2016. The river bank's construction was found cracked up to 570 meters long. From the case above the State Civil Servants relating to the standard operating procedures above have been examined by the Denpasar District 
Attorney. This has led to massive concerns or fears among the bureaucracy over the procurement of goods and services which often ends and deals with law enforcement officials, either directly or indirectly. This condition is proven by the fact that the problems are handled by law enforcement officers from the National to Regional level, of which $56 \%$ comes from the government procurement process (Corruption Eradication Commission, 2015). The psychological pressure of work experienced by the State Civil Servants in carrying out its main duty and function as the procurement executor of government goods / services, needed a place or institution to consult with the purpose of providing motivation and assistance to the procurement of government goods / services. Work psychology is a psychological study of how human resources (HR) work within an organizational environment (Ndraha, 1999).

The inconvenience in this bureaucratic environment has inspired the State Civil Servants (ASN) to strengthen and fortify themselves from tasks related to the procurement process of government goods / services both within the internal of ULP itself and within the Government of Badung Regency. Thus, in the Year 2017 came the idea to develop an idea about the establishment of government procurement of goods / services Clinic at ULP Badung Regency. ULP Clinic of Badung Regency is actively involved in 3 (three) functions namely: planning of procurement, selection of providers of goods / services and procurement implementation functions.

An interesting thing to learn next is about the procurement clinic which is an integral part of ULP Badung Regency. It was established in order to carry out the implementation of ULP Pilot. Definitely the term of "clinic" is always associated with the world of health, it does exist in the ULP of Badung Regency which actually is not related to the duties and functions of services in the field of health.

Based on the background of the problems that have been described, then the main problem in this research is what is the meaning behind the establishment of Clinic of Government Procurement of Goods / Services of ULP of Badung Regency? Based on the subject matter, the purpose of this study is to expose the meaning of the Procurement Clinic of Government Goods / Services at Badung Regency ULP. The results of this study can provide useful benefits and contributions to the academic world, especially in relation to the existence of Clinic of Government Procurement of Goods / Services of Badung Regency in order to realize good governance. In addition, this study provides the Theory of Need relevance to the meaning behind the establishment of the Clinic.

\section{THEORETICAL FRAMEWORK}

The theory of needs (Maslow, 1943) is a hierarchy of needs theory contains a basic human need. Maslow describes it as a level or ladder of need. According to Maslow, the hierarchy of needs is driven by two forces, namely the motivation of shortcomings, and the motivation of development or growth. Motivation of shortcomings, aims to overcome human tension on the lack of existing needs. The motivation of development or need is based on the human capacity to grow and develop. As mentioned above, Maslow's hierarchy of needs has five levels, i.e.:

- Physiological needs, a body's biological needs include food, water, oxygen, and normal body temperature. Physiological needs are the first basic need that human beings seek to achieve life satisfaction. If one of these needs is not obtained, it will disrupt the fulfillment of the other basic needs.

- The need for security and safety, including the need for job security, freedom from fear or pressure, security from a threatening event or environment.

- The need for a sense of belonging, social and compassion, encompasses the need for friendship, family, grouping, interaction and affection.

- The need for respect (esteem), after the above three needs are met, human beings will pursue the need for appreciation, such as respect for others, status, fame, reputation, attention, and so on. According to Maslow, the need for appreciation is also divided into two levels: low and high levels. Low levels namely the need to 
respect others, the need for status, fame, reputation, attention, appreciation, dignity, and domination. High demand is the need for self-esteem such as feelings, beliefs, competencies, achievements, mastery, independence, and freedom. Maslow argues, if the need for self-esteem has been resolved, then humans are ready to meet the needs at a higher level again.

- The need for self-actualization, including the need to attain self-existence through maximizing the use of capability and self-potential. Self-actualization needs are the highest level of need. This need involves a constant desire to reach the potential. According to Maslow, this need is the need that man has to involve himself to be what he/she wants according to his/her ability. Human being will fulfill his/her desire in accordance with the ability possessed in a person. Self-actualization described by Maslow is as follows: the Unit of Procurement Services (ULP) is a unit of government organization that works to implement the procurement of goods / services in permanent state of $\mathrm{K} / \mathrm{L} / \mathrm{D} / \mathrm{I}$, which can be stand-alone or attached to an existing unit (LKPP, 2011).

Procurement Unit of Badung Regency. The Procurement Service Unit (ULP) of Badung Regency was established with the composition that considering the work load which is the consequence of the annual Badung Regional Budget (APBD). The consideration resulted in the organization of the Procurement Unit of Badung Regency consisting of 9 (Nine) Working Groups (Pokja), each working group consists of 5 (five) people with the composition of 1 (one) chairman of the working group, 1 (one) secretary, and 3 (three) members, and supported by the secretariat to handle administrative matters. Procurement Unit of Badung Regency is an independent procurement service unit in the Goods / Service Procurement Division of Badung Regency, which is the principal agency and its function as the executor of the selection of government goods / service procurement providers in Badung Regency.

Procurement of Government Goods / Services. Procurement of Government Goods / Services is an activity to obtain goods / services by Ministries / Institutions / Agencies / Governmental Institutions (K / L / D / I) whereby the process begins with the planning of needs until the completion of all activities to obtain goods / services, financing partly or wholly derived from the State Revenue Budget (APBN) or Regional Revenue Budget (APBD), (Sutedi, 2012). Public Procurement is an acquisition process undertaken by government and public institutions to obtain goods, works, and services transparently, effectively and efficiently in accordance with the needs and desires of its users. In this case, the user can be an individual (official), an organizational unit (department, faculty, etc.), or a wider community group. (Edquist, C., Hommen, L., and Tsipouri, 2000).

Procurement Clinic of Government Goods / Services. Clinic is a health service facility that conducts individual health services that make basic or special medical services (Health Minister Regulation No. 9 of 2014). According to the Government Procurement Policy Agency (LKPP) in cooperation with Millennium Challenge Corporation (MC-Al) that procurement clinic in addition to performing its duties and functions as ULP procurement personnel, it also functions as a procurement clinic. Procurement Clinics can provide assistance and coaching and facilitation activities to procurement personnel inside and outside the ULP including procurement personnel in the Organization of Regional Devices (OPD).

Phenomenology. Phenomenology is the result of a reflection of philosophical thought (Husserl, 1989) as a radical new way of philosophizing. Later this theory was further developed by (Schuetz, 1944) and (Heidegger, 1962). Heidegger focuses on the awareness and essence of phenomena against elaborating existential and hermeneutic interpretative dimensions (Finlay, 2009).

The term phenomenology comes from the Greek "Phainomenon" which refers to the visible (Berrios, 1989, Harbiansyah, 2005) and "logos" which is defined as knowledge, discourse, reason or judgment (J. Smith, 2007). The essence of phenomenology is to describe and explain the uniqueness of life experience from the essence of a particular phenomenon (Diaz, 2015, Harbiansyah, 2005; Kuswarno, 2006; Sanders, 1982; Sudarsyah, 2013; Sukoharsono, 2006). In order to do so, Phenomenology seeks to explore the structure 
of awareness and understanding of the experience of the people who experience it (Asih, 2005; Grace, 2009; Sandberg, 2005; Sukoharsono, 2006).

The phenomenological approach seeks to let reality reveal itself naturally (Harbiansyah, 2004). Through "inducement questions", the subject of research is left to tell all sorts of dimensions of its experience with regard to a phenomenon (Harbiansyah, 2005). The advantage of the method of phenomenology is that it will be able to bring the research to the most objective and neutral position in the subjective space that is able to highlight the importance of a phenomenon (Darmayasa \& Aneswari, 2015). According to (Sanders, 1982) the steps that need to be done in the method of phenomenology include: intentional analysis, epoche and Eidetic reduction.

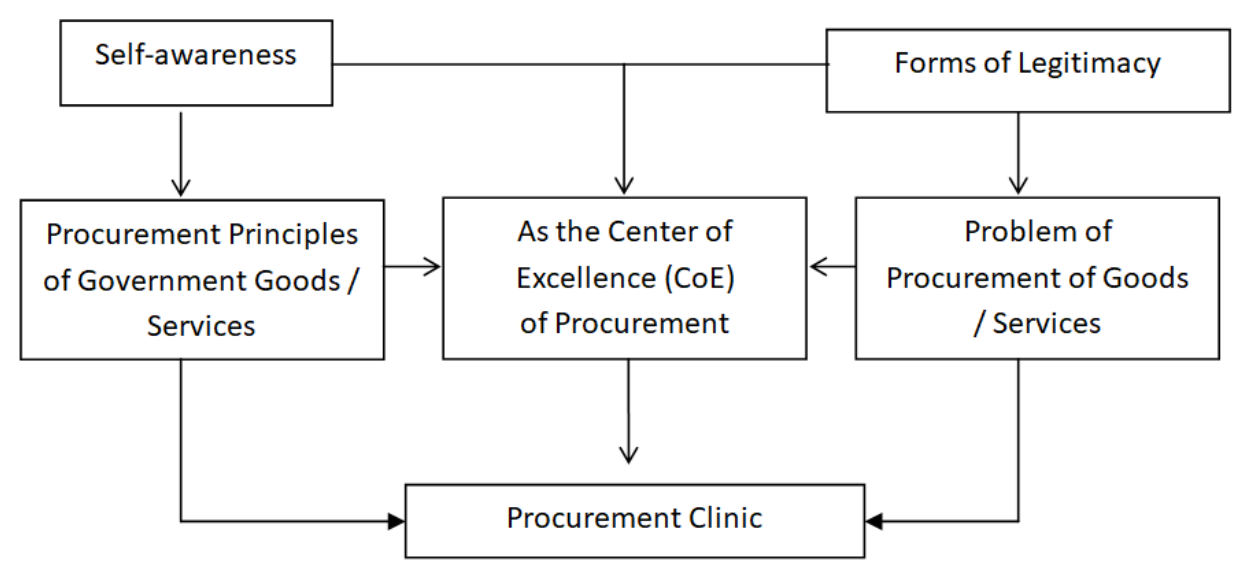

Figure 1 - Research Concept

Research Preparation

1). Determining the focus of research

2). Library Research

3). Create a framework of thinking

Determination of informants who established Procurement Clinic of Government Goods / Services at ULP of Badung Regency

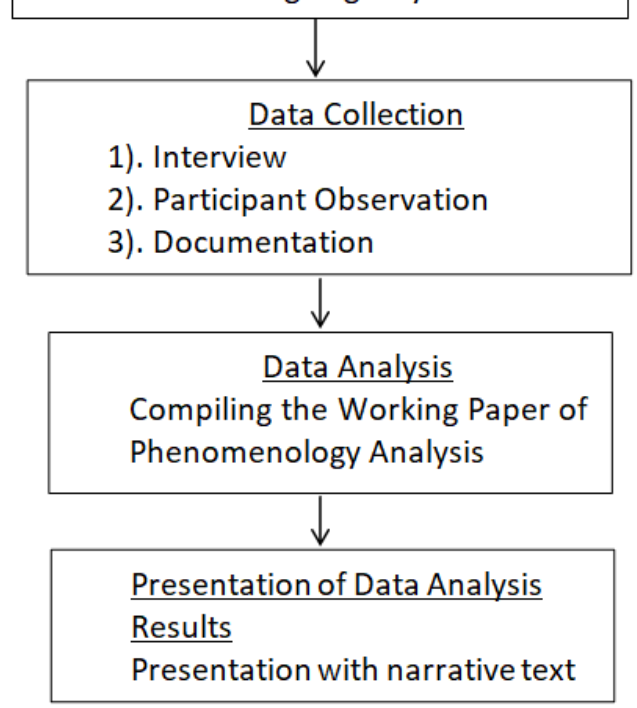

Figure 2 - Research model 
Phenomenology uses two concepts of noesis and noema to reveal intentionality. Intentionality refers to the correlation between noema and noesis leading to interpretation of experience. Noema is an objective statement of behavior or experience as reality, whereas noesis is the subjective reflection of the objective statement (Sudarsyah, 2013). Intentional analysis is the process of exploring one's experience (noema) to derive the essence of its consciousness (noesis) by doing epoche application.

This study uses transcendental phenomenology as a research method, because this method is very appropriate to describe the direct desire of informants, to convey their desire to a phenomenon, which is about the establishment of Procurement Clinic of Government Goods / Services.

Procurement Clinic of Goods / Services in ULP Badung Regency was established as a manifestation of dedication Badung ULP as Center of Excellence and to carry out its guidance to the procurement of goods / services of the Government. Based on the explanation above, this concept is presented in the Figure 1.

\section{METHODS OF RESEARCH}

Research paradigm. Perception about humans through the interpretive paradigm mentioned that humans create reality through subjective meaning, which ultimately form a pattern of interaction through the systems of meaning. This study used the interpretive paradigm to understand and explain the phenomenon of the establishment of Procurement Clinic of Government Goods / Services at ULP of Badung Regency. The interpretive paradigm encompasses a wide range of philosophical and sociological thoughts that have the main characteristics for understanding and explaining the social world especially in the viewpoint of those directly involved in social processes (Burrell, G., \& Morgan, 1979).

Research Approach. The approach of this research is qualitative approach. This research intends to reveal the essence behind the meaning of the establishment of Procurement Clinic of Government Goods / Services at ULP of Badung Regency. The research approach used is Phenomenology with the aim to reveal how informants interpret a phenomenon, so that the essence of the phenomenon will look natural without the researcher's intervention. There are several notions of phenomenology according to (Husserl, 1989) such as: (a) subjective or phenomenological experience, (b) a study of consciousness from the fundamental perspective of a person. It is understandable that phenomenological research is a thinking view that emphasizes human experiences and how humans interpret their experiences.

Research Location. This research was conducted at Badung Service Procurement Unit located at Jalan Raya Sempidi Badung Regency Civic Center.

Types and Data Sources. The type of data used in this study is qualitative data, i.e. subject data that includes opinions, attitudes, experiences, or characteristics of the informants consisting of the practitioners concerned. Based on data sources, this study uses primary data, a direct source (not through intermediary media). Primary data in this study were obtained from direct search and through unstructured and in-depth interviews with key personnel from Badung Regency ULP.

Informants of Research. The selection of informants was conducted purposively, based on certain criteria, namely:

- The decision makers in Badung Regency ULP;

- The initiator of the idea of a procurement clinic of government goods and services.

Based on the criteria that were outlined, while the informants of the research were:

- Secretary of ULP of Badung Regency as initiator of idea of establishing government goods/services procurement clinic;

- Chairman of the Working Group of ULP of Badung Regency as well as a mentor or a procurement champion.

Methods and Techniques of Data Collection. Data collection techniques is the most strategic step in the research, because the main purpose of research is to get data (Sugiyono, 2010). Data collection techniques used in this study was conducted through: 
- Interviews, in the study of phenomenology, it would have been extremely ineffective for phenomenologists to prepare a set of questions, since precisely these structured questions would keep the phenomenologist from the process of "disclosure" the consciousness (Kamayanti, 2016).

- Participatory observation is a data collection method used to collect research data through observation and sensing where the observer or researcher is really involved in the respondent's daily life (Bungin, 2007).

- Documentation Techniques, the notion of the word document according to (Gottschalk, 1985) is a process of proof based on any kind of source, whether written, verbal, or archaeological ones.

Methods and Techniques of Data Analysis. There are several key words in the analysis of phenomenological studies, as follows (Kamayanti, 2016): Noema; Noesis; Epoche (Bracketing); Intentional Analysis; Eidetic Reduction.

Qualitative Data Validity Examination Techniques. Testing of the validity of data in qualitative research includes the following criteria (Moleong LJ, 2013).

- Credibility (Validity Internal), the steps undertaken in this study include (1) making notes on interviews with informants and then (2) to cross check the records of the material to ensure no conflicting information between the notes of the interview. After that (3) the confirmation results had to be tested again with the previous information because it could contradict with the information that has been collected previously from the informants or other sources.

- Transferability (External Validity), this transfer value is related to the question, to which extent the research can be applied or used in other situations?

- Dependability (Reliability), whether the research results refer to the consistency of the researcher in collecting data, forming, and using concepts when making interpretations to draw conclusions.

- Confirmability, whether the results of research can be verified, or the results of the study are in accordance with the data collected and included in the field report. This was done by discussing the results of the research with the informants.

Methods and Techniques of Presentation of Data Analysis Results. The presentation technique of data analysis result is intended to write systematically about the research results. The results are presented in descriptions according to the data set. Data in the form of statements or opinions from interviews are presented in narrative form or informally in scientific language.

Disclosure of meaning behind the existence of procurement clinic of government goods and services in the unit of procurement services of Badung Regency:

Interpretation of Informant S. Interpretation of informant $S$ stated that the existence of the procurement clinic of government goods and services is an idea that came spontaneously from Mr. I Made Sudarsana, SE (noema) which has been appreciated by the Policy Institute for Procurement of Goods / Services (LKPP), as a medium for consultation about the procurement process of goods / services along with the problems as well as a form of real appreciation and contribution to LKPP for giving three years of training on Procurement Modernization (noesis).

The theory of needs (Maslow, 1943) on the hierarchy of esteem needs stating that, at this stage someone needs include the desire to gain self-esteem. This self-esteem or selfrespect depends on the desire or strength, competence, freedom and independence. This need is closely related to the achievement, motivation, drive for achievement. Through motivation, it is hoped that one can work and fulfill the job with a passionate spirit because it is based on a strong desire to do so (Terry \& Rue, 2003), so that the objectives of the apparatus and the organization can be achieved (Flippo \& Masud, 1995). The existence of the procurement clinic of goods / services other than as a place to carry out consultations, it is also used to assist the State Civil Servants, which is still hesitant and worried about the procurement of government goods / services. Employee fears indicate that there is pressure on working psychology, where the psychological study examines how human resources work 
within an organizational environment (Ndraha, 1999). The theory of needs (Maslow, 1943) on the hierarchy of the second place mentions the importance of safety and security needs or the need for security.

The dynamics of rapid regulation is another problem in the provision of government goods and services. The regulation is about procurement of government goods / services, and this is not followed by the State Civil Servants to keep on learning so that they become less aware of existing regulations and the procurement process of government goods / services. Rapid regulatory changes are not kept up by the State Civil Servants caused by the lack of learning organization so that the understanding of the procurement of government goods / services is not achieved. Learning organizations are a way for organizations to create, acquire, and transfer knowledge, and modify behaviors to reflect new knowledge and insights in organizations (Garvin, Edmondson, \& Gino, 2008). This confirms that learning organization is very important for an organization and its human resources as a learning process that can increase competitive advantage in this increasingly competitive business environment.

The goods / service procurement clinic is established to solve the problems that exist at each stage of procurement such as planning, budgeting, selection and contract implementation. For Informant $S$, it is very important to provide good service in the goods / services procurement clinic in the hope of improving the quality of services provided to the parties related to the procurement of goods / services government. Quality of service is a comparison of what the consumers have expected with the services they received. An organization, the concept of service quality becomes a measure of organizational success, the success of an organization means both in the business organization and also on the organization that is in charge of providing public services (Samosir 2005).

Procurement clinic of government goods / services of Badung Regency, strongly supports the favorable conditions for any apparatus that have the main duty and function as the procurement of government goods / services. Professional public services means accountable and responsible public services of the service providers (government apparatus).

Interpretation of Informant $U$. The establishment of the government procurement clinic is an idea of Mr. I Made Sudarsana, SE (noema). As more and more complex problems in the implementation of procurement of goods / services government, communication media and consultation is needed to obtain a solution to the problem (noesis). Officially the parties consulted are accepted at the goods / services procurement clinic. The apparatus providing such consultancy is not limited to procurement champions only, but rather to all the chairmen and secretaries of working groups (pokja), who have attended the procurement modernization training held by LKPP. Clinic of procurement of goods / services was formed because of the more and more complex problems that occur in the procurement process of goods / services, so it needs a kind of communication media for consultation on the problems in the process and implementation of government procurement of goods / services.

Benefits obtained from the government goods and services procurement clinic can be viewed from two sides, firstly, as a way or means to solve problems related to the procurement of goods and services. Secondly, to provide education to the parties related to the procurement of goods and services, how to avoid similar problems in the following years. As an effort to develop human resources through education and training in an effort to improve employees' performances. The need for organizations to provide education and training for their employees, because through education and training, it is expected to help employees reach to a higher level in the composition of employees and the organization as a whole (Moenir, 1995).

Procurement problems arise due to lack of understanding of the apparatus on how the procurement process of goods / services, whether in terms of planning, budgeting, selection, implementation, evaluation and monitoring until the goods / services are recognized as assets. Education and training are needed by the apparatus who has the main duty and function on the implementation of government procurement of goods / services with the aim of avoiding the procurement problems. The optimization of the success of a project is 
determined by the planned organization by using available resources and tools with appropriate time of planning, and by using information technology (Kerzner \& Saladis, 2011; Larson \& Gray, 2013).

In fact, procurement clinic of goods / services for apparatus in the Unit Procurement Services turns out to cause more work loads because of the overlapping of work. Counselors and consultants at the procurement clinic run out of time to serve parties who wish to carry out consultations on procurement of goods / services. A public organization needs to see the ability of the Apparatus in terms of providing workload in accordance with its ability, so that the Apparatus can perform its duties properly (Sutarto, 2006). Workload is a burden for doing too many tasks or providing insufficient time to get the job done (Gibson, Ivancevich, Donnelly, \& Konopaske, 1991). Higher workloads make consultants at the procurement clinic manage the time in such a way that all works, whether as their main tasks and functions or as professional consultants can be completed on time.

The problem of procurement of goods / services that can be completed in the procurement clinic has a positive impact on the organization. Not only the issue of procurement, but also the non-domain of the clinic. It adds a positive image and more recognition of the existence of the procurement clinic of goods / services.

Clinic procurement of goods / services is expected to provide professional and effective services. Professional means accountable and responsible public service from the service providers while effective means prioritizing on achieving what are the goals and objectives. Problem centering at the level of need for self-actualization is empathy to help others solve the problem. Finding the most effective solution to any problem, whether it is outside or inside of themselves (Maslow, 1943).

The increased understanding of the government procurement process of goods / services is expected to provide synergy between stakeholders related to the procurement of goods / services. This synergy begins with the planning of the OPD and its implementation by the Regional Development Planning Agency (Bappeda). It synergizes with the ULP as a service provider, the Finance Agency, and the Asset Department as the regional asset recorder. The parties involved should be able to work together, appreciate the difference of ideas and be willing to share (Covey, 2013). Synergy is urgently needed between stakeholders or interlinked stakeholders to produce better and greater output, this can be built with communication and coordination (Najiati, 2011).

Interpretation of the Researcher. Noema obtained from the researcher is the idea that came spontaneously from the Informant $S$ and it is also the form of appreciation towards the reward given through training of procurement modernization by the Government Procurement Goods / Services Institution. Noesis obtained is the desire to make a media as a place to consult on the problems that occur in the procurement of goods and services and provide a positive image for the procurement clinicof goods and services.

The idea came because there was no media to consult about the problems of procurement of goods / services. Not apart from the spirit of Central of Excellent, this clinic was established after getting three years training on procurement modernization organized by LKPP in cooperation with Mc-I. The problems that arise in the government procurement of goods / services mainly because of lack of understanding of the apparatus that has the main tasks and functions on the implementation of government goods / services, and the regulation changes very quickly so it is an obligation for the Apparatus to continue to learn and improve understanding of the procurement process of goods / services. Lack of understanding of the procurement process of goods / services experienced by the apparatus such as in planning, budgeting, selection, evaluation and monitoring, contract implementation and asset inventory of the local government. This statement is supported by (Kotler et al., 2005) noting that the process of activity includes everything that is interconnected and related to the procurement process of goods and services. In the implementation there are several factors that must be considered by the procurement unit namely, planning or strategy approach that must be in accordance with the grace period and then adjusted for the cost to be incurred. A well-planned project should begin by separating the types of activities, processes to be taken, cost budgeting, labor and contract predictions (Maylor et al., 2006). 
The problems that often occur in the procurement of government goods / services is the rapid change of regulation, thus demanding the apparatus and related parties to continue to learn and improve the ability in the field of procurement of goods / services. Learning Organization has seven dimensions, namely: creating continuous learning opportunities, developing discussions, encouraging collaboration and team learning, providing opportunities for employees to achieve common goals and shaping leadership that has learning strategies (Marsick \& Watkins, 2003). Learning Organization is an organization's way of skillfully creating, acquiring and transferring knowledge, and modifying behaviors to reflect new knowledge and insights into the organization. The problem usually will be consulted to the procurement clinic of goods / services, this is not apart from the function of the clinic, i.e. to provide services to the public maximally. Responsiveness is an element of public service that leads to responsiveness and quickly responds to issues, needs and aspirations of the people (Effendi, 1991).

The existence of procurement clinic of goods / services is expected to provide solutions of all problems that occur in the goods / services procurement. This is related to the problem centering of the characteristics of the need for self-actualization (Maslow, 1943). Problem centering, having a sense of helping others solve the problem, finding the most effective solution to the problem. This happens even when problems occur outside or inside of their personal surroundings. Motivation for a sense of responsibility and social ethics is the basis of its will. A person who actualizes all his/her thoughts, behaviors and ideas is not based on his own good, but based on the public interest (Kozier, Erb, Berman, \& Snyder 1998).

Apparatus whose main duties and functions relate to the procurement of goods / services undertake coordination and consultation to the procurement clinic in order to convince themselves that what they are doing is correct and not contrary to the existing regulations. The theory of needs (Maslow, 1943) mentions the importance of the need for security because of the awareness of the limits of each individual so that the importance of the other party to provide security for them. Security and safety needs include the need for job security, independence from fear or pressure, security from an event or a threatening environment. This is in line with the opinions of (Luthans, 2002; Robbins, Judge, \& Breward, 2003) that employees are usually very concerned about their workplace environment for personal comfort and to support their work. They tend to prefer security protection to work. The more number of parties who consult the procurement clinic, it is expected that human resources available in the procurement clinic to improve professionalism in the field of procurement of goods / services. A professionally run public service will be able to provide resposive service and accountability. The key factor in providing public services is to do good, honest and focused service on the work being done.

Clinic procurement of goods / services for the Apparatus in ULP itself, it resulted in more work loads caused by the overlap of work. Apparatus assigned as mentors or consultants have time-sharing issues, in which they are also required to complete selection of goods / service providers in a timely manner because of the large number of auction packages that must be worked on and it demands a high level of accuracy. A high level of accuracy is required in order to avoid errors in evaluation of provider selection so that the selected provider is believed to be capable of carrying out the execution of the work. The use of work time required to complete the work indicates that although all work is always well resolved but the work time of the employees at certain times becomes increased until outside of working hours or holidays, resulting in a workload for employees (Tarwaka, 2011). The workload experienced by the Apparatus at the goods / service procurement clinic is anticipated by the creation of a service schedule, which commissioned alternately assisting parties implementing the government procurement of goods / services. The schedule is expected to reduce the workload of the mentors so that all work can be completed properly and on time and avoid losses for any party.

Government procurement clinic of goods / services is a place for the parties whose duties and functions are related to the procurement of goods / services to carry out coordination and consultation related to the procurement process of goods / services. It is so important that the existence of a clinic for procurement of goods / services. Therefore, more 
and more parties are doing consultation to the procurement clinic. It illustrates that the existence of the goods / services procurement clinic provides a positive image, in which the procurement clinic is necessary for the parties concerned so that they are confident and understand the process of procurement of goods / services well. Image is a community perception of the organization based on what they know or think about the organization (Kotler et al., 2005). More broadly mentioned that image is the beliefs, images, and impressions that one believes in an object. The image of an organization describes the values of a person and the groups of people who are related to the organization. A positive image needs to be built honestly so that the image perceived by the public is good and right, in the sense that there is consistency between image and reality. Positive public opinion is formed from a positive image of an institution or organization, generally there is a good and positive relationship between the public with the organization. The positive image in Maslow's needs theory includes the need for reward (esteem). The need for appreciation, recognition from the organization or society arises because of an achievement of work and prestige from the leadership of the organization (Hasibuan, 2002). Job performance is a measure of one's success in completing a given task or job (Ismail, 2010).

Procurement clinic of government goods and services aims to provide capabilities for parties involved in the procurement of goods / services to better understand the process of procurement of goods / services. The better understanding on how the process of the implementation of goods / services of government, it is expected to provide motivation to work so that every apparatus has the skills and professionals in the field of procurement of goods and services. Factors influencing one's skill include belief, skill, motivation, intellectual ability and organizational culture (Fahmi, 2016). Maslow's theory of needs in (Suwatno \& Priansa, 2011) mentions that motivation is formed because of the hierarchy of needs, so that by the motivation of work, it is expected that individuals are willing to work hard and enthusiastic to improve the ability and productivity of work (Hasibuan, 2002). An increasing understanding of the government procurement of goods / services is expected to provide synergy between stakeholders related to the government procurement of goods / services. The synergy is starting from the planning process of the organization, the implementation of budgeting carried out by the Regional Development Planning Board, then synergizing with the selection process of existing providers in ULP, in synergy with the Financial Institution as the party who will pay the completion of the activity and the last one in synergy with the Section assets that will record how many assets owned by the government. Well-realized synergies will be able to minimize the problems that occur in the field of procurement of goods / services government. Synergy can be built through good coordination and communication between stakeholders to achieve common goals (Najiati, 2011).

\section{CONCLUSION}

Based on the analysis and discussion, it can be concluded that the parties involved in the disclosure behind the existence of the government procurement clinic of goods and services at the Procurement Unit of Badung Regency has understood the phenomenon. Noema expressed by the two informants has similarities, but the expressed Noesis has a difference.

Noema of disclosure of the meaning behind the existence of a government procurement clinic at the Procurement Service Unit of Badung Regency is an idea born from the thought of Mr. I Made Sudarsana. While Noesis from the disclosure of the meaning behind the existence of the government procurement clinic of goods / services at the Service Unit Procurement of Badung Regency namely:

- As a place to carry out consultations on various problems that occur in the process of procurement of government goods / services for the Apparatus and the parties related to the procurement of goods / services.

- As a concrete manifestation of the reward given, in the form of procurement modernization training for three years. 
- The existence of a government procurement / clothing clinic causes an increase in the workload for the Apparatus in the Procurement Unit of Badung Regency, because in addition to completing the main work, namely the selection of procurement of goods / services, the also function as mentors or consultants for the parties who ask for coordination and consultation at the procurement clinic.

- The number of parties to coordinate and consult, improve the positive image of the procurement clinic of government goods / services.

\section{SUGGESTIONS}

The Husserl's Transcendental Phenomenology Study has been able to uncover the meaning of the phenomenon of the existence of the government procurement clinic at the Procurement Service Unit of Badung Regency. There are several things that the study can recommend according to the results of this study, among others:

- It is advisable that the outcomes of consultation to be formally documented for references to solve the same problem at the next consultation;

- Based on the problems consulted, it can be formulated a solution to be a learning material for OPD through Technical Guidance of capacity building in goods / services procurement process;

- The government is expected to immediately make a formal legal or regulatory umbrella for the existence of procurement clinic of goods / services in carrying out its duties and functions.

\section{ACKNOWLEDGMENTS}

Author would like to express deepest gratitude to Dr. I Gusti Ayu Nyoman Budiasih (SE, M.Si) as an academic adviser who has spent his valuable time guiding and giving excellent advices for preparing and compiling this paper.

\section{REFERENCES}

1. Nisjar, K. (1997). Jurnal Administrasi and Pembangunan. Beberapa Catatan Penting "Good Governance," 1(2), 119.

2. Smith, B. (1985). Decentralization the Territorial Dimension of the State. Allen \& Unwin.

3. Simamora, S. (2013). Hukum Kontrak: Kontrak Pengadaan Barang and Jasa Pemerintah di Indonesia. Surabaya: Laksbang Justitia.

4. Due, J. F., \& Friedlaender, R. J. (1993). Keuangan Daerah, Perekonomian Sektor Publik. Alih Bahasa: Rudi Sitompul, Erlangga, Jakarta.

5. Sutedi, A. (2012). Good Corporate Governance. Jakarta: Sinar Grafika.

6. Marbun, R. (2010). PemerintahPengadaan Barang/Jasa. Jakarta: Media Jakarta.

7. Ndraha, T. (1999). Pengantar Teori Pengembangan Sumber Daya Manusia. Rineka Cipta, Jakarta.

8. Maslow, A. H. (1943). A theory of human motivation. Psychological Review, 50(4), 370.

9. Edquist, C., Hommen, L., Tsipouri, L. (Eds.). (2000). Public Technology Procurement and Innovation. Boston/Dordrecht/London: Kluwer Academic Publishers.

10. Husserl. (1989). Ideas Pertaining to a Pure Phenomenology and to a Phenomenological Philosophy Second Book studies in the phenomenology of constitution. Netherlands.

11. Heidegger, M. (1962). Being and time. 1927. Trans. John Macquarrie and Edward Robinson. New York: Harper.

12. Schuetz, A. (1944). Philosophy and Phenomenological Research, 5(4), 533-576.

13. Berrios, G. E. (1989). What is Phenomenology? A review. Journal of the Royal Society of Medicine, 82, 425-428.

14. Bungin, B. (2007). Analisis data penelitian kualitatif. PT RajaGrafindo Persada.

15. Burrell, G., \& Morgan, G. (1979). burrel. Siciological Paradigms and Organisational Analysis - Elements of the Siciology of Corporate Life, 1, 448. 